\title{
BIR KITAP VE DÜŞÜNDÜRDÜKLERI
}

\author{
Yrd. Doç. Dr. Bilge CRISS
}

ERIK JAN ZÜRCHER, Political Opposition in the Early Turkish Republic: The Progressive Republican Party 1924-1925. Leiden: E. J. Brill, 1991. Terakkiperver Cumhuriyet Furkası. Çevirmen, Gül Çą̧alı Güven Istanbul: Baglam Yayıncılık, 1992.

Kurtuluş Savaşında lttihatçılık adı eseriyle tanınan Prof. Zürcher, dilimize çevrilen ikinci kitabında Terakkiperver Cumhuriyet. Fırkasını inceliyor. Bu çalışma, birincisinin doğal bir uzanusı. Aynca, günümüz Türkiye'sinin gündeminde olan II. Cumhuriyet, veya halifelik kaldınılmasaydı daha $\mathrm{m} ı$ iyi olurdu gibi tâli de olsa sorgulanan konulara çıkarsama ile bağlı olduğu için düşünđürücü ve önemli bir yapıt. Kitabın başında da belirtildiği gibi, 1924'ün Kasım ayında kurulan TCF, Kurtuluş Savaşının onderleri arasındaki rekabetin son aşamasıyd. Ülkenin geleceği üzerinde kimlerin ve nasıl söz sahibi olacağının belirlenmesine dayanan bu rekabet, direnişin başladı $\breve{g}_{1} 1919$ 'dan Türkiye Cumhuriyetinin ilân edilmesine kadar zaten süregiden bir mücadeleydi. TCF'nin 1925 'de kapatılması ise, II. Dünya Savaşının sonuna kadar sürecek tek parti "diktatơrlügüune" yol açacaku.

Yazar her ne kadar diktatörlük sözcügünü rahatlıkla kullanıyorsa da, biçimsel olarak gerçek olan bu olgunun $1920^{\prime} l i, 30^{\prime}$ lu ve $40^{\prime}$ 'l yillarda Avrupa ve Sovyetler Birliğinde var olan tek parti diktatörlǚ̆üyle özdeş olmadız̆ını belirtmemesi belki de kitabın eleştiriye en açı yanlanndan biri. Onun yerine Maurice Duverger bunu Siyasi Partiler adlı kitapıa yapmış (Çev. Ergun Ozbudun, Bilgi Yayınevi, 1992).

... Türk tek partisinin yapısında totaliter bir taraf yoktu. Bu yapı ne hücrelere, ne milise, ne de gerçek anlamda ocaklara dayanıyordu. Parti kütlelere siyasi eğitim vermek amacıyla birçok açık toplantılar, halk meclisleri ve kongreler düzenlemişti. Üyelik herkese açıktı. Ihrą̧ ve temizlik mekảnizması mevcut değildi, üniformalar, geçit resimleri ve sert bir disiplin yoktu. Gerçekte parti içi demokrasi de oldukça ileri görünmekteydi... Faşist rejimlerde hergün rastlanan otorite savunusunun yerini Kemalist Türkiye'de demokrasi savunusu almışur. Türk tek parti sistemi hiçbir zaman bir tek parti doktrinine dayanmamıs, tekele resmi bir nitelik vermemiş, liberal demokrasiyi ortadan kaldırma

\footnotetext{
* Bilkent Oniversitesi Oggretim Oyesi
} 
arzusuyla meşrulaşmaya çalışmamıştır. Sahip olduğu tekelden daima rahatsızlık, hatta bir utanç duymuştur. Kemal, çeşitli fırsatlarda bu tekele bir son vermeye çalışmıştır ki, bu olgu tek başına bile derin bir anlam taşımaktadır. Hitler Almanya'sında ya da Mussolini ttalya'sında böyle bir şey düşünülemezdi. (Oktay Akbal, "Neden Yeni Model Aramak?" Milliyet, 2 Mart 1993, s. 13)

Yukarıdaki gibi somut kıyaslamalar yapılacak olursa, 1923-1945 arasındaki Avrupa ve SSCB diktatörlükleriyle Türkiye'deki tek parti yönetiminin nitelik ve nicelik açısından çok farklı olduğu ortadadır. Bu yaklaşım tek parti yơnetimini haklı çıkartmak kaygısıyla yapılan kişisel bir değer yargısı deł̧il, tarih metodolojisinde hiçbir olgunun siyah veya beyaz olmadığını, çok daha zengin renk tonlanyla dolu olduğunu vurgulama istełimden kaynaklanıyor. Kaldı ki, ancak diłger ülkelerle kıyaslama yapıldığı takdirde Tek Adamlıłın, Ebedi Seflił̧in ve, Tek Parti Egemenliģinin dozu saptanabilir. Bununla beraber, dełerli meslektaşım Erik Zürcher yakın tarihimizi çok seslilik girişimi açısından aydınlatmakta son derece başarılı bir deneyimde bulunmuştur. En azından bu okurunu iki konu ỉzerinde düşünmeye sevketti: TCFnın siyasi boyutu ve tarih metodolojisi.

Cok kısa sürede kőklï bir ulusçuluk yaratmak isteyen Türk Cumhuriyetçileri bu ulusçuluğun tiirdeş olmasını óngörüyorlardı. Bu nedenle, parlamenter demokrasi bir ideal olmaya mahkûm olurken, Tek Parti iktidarı hep zorunlu bir geçiş dönemi olarak kaldı. Gerek tarih yazımında gerek iletişim organlannda iktidann meşru olduğu, muhálefetin ise meşru olmadığı tezi şimdiye dek işlenmiştir. Belki de günümüz demokratikleşme sanculannda üstü kapalı veya açuk hâlâ bu olgu yatıyor. Genç Cumhuriyetin ilk yıllarında hoşgörülebilecek bu durum, 70 yıl sonra hâlâ gündemde ve kolaycılık yőntemiyle kőylü toplumdan kafa yapısı olarak şehir toplumuna dönüşüm sancılarının faturası günümüzde hâlâ Kemalizme çıkartılabiliyor. Tarihsel süreçlerin ivmesi insan malzemesinin kalitesiyle dợru oranulı ise, en azından bugünü açılamak zorunda olan tarih, kıyaslama metoduyla dünümüzü nitelik açısından saygıyla anmak durumuna gelmiştir. Ancak metod açısından tarihselcilikle -yani dogrunun tarihsel gobreceligine inanmakla- evrensel "dogrular" arasında bir kőprü oluşturabilmek gerekli. Bu da belki metodoloji bilincinin yazım inceliklerine uyarılımlanna baglı olabilir. Kendininkinden apayn bir politik kültürüi inceleyen her tarihçi için ise bu başlıbaşına bir sorun.

Kitap içerik olarak irdelenecek olursa, onncelikle TCF'nın ónemi hem Cumhuriyet doneminin ilk muhalefet partisi olmasından, hem de ilk kez radikal ve otoriter Kemalizme karşı belki de güvenilebilecek bir alternatif olarak ortaya atılmasından kaynaklanıyor. Bu noktadaki varsayım geriye bakarak bir óngörü oluşturduğundan, värsayımın sorgulaması da gönülsüz olarak bir spekülasyonu çağnşıracak. TCF iktidara gelebilseydi, içindeki asker ve sivil kökenli, ve her biri gene Osmanlı elitinden oluşan şahsiyetler nedeniyle otoriterlik ölçülerinin Kemalistlerden daha az olacağını mutlak bir varsayım olarak kabullenebilir miyiz? Prof. Zürcher ozel sohbetimiz sırasında bunun mutlak bir varsayım değil sadece elindeki parti programına dayanarak vardığ bir sonuç olduğunu sóyledi. Belge bağımlılığı bazen yanıltıcı olabileceği için zaten yazar da kendini bu bulgularla sinırlandırmayıp, kitabı "büyüleyici, ancak yanıtlanamaz" diye nitelendirdiği soruyla bitiriyor: "Yoksa, TCF'nin de onemli bir bağlantı işlevi görebileceği lkinci Meşrutiyet ile Kemalizm sonrası dönem arasında gerçck bir devamlılık olsayḍ, demokratik sisteme dogru bir gelişme çok daha kolay mı olurdu?"

Hemekadar TCFnnin parti programı ekonomik ve politik liberalizmi on plana çıkaryyor ise de, yıkıcı savaşlar ve Osmanlı borçlarının yüklenilmesinin ertesinde büyük 
bir olasılıkla ekonomik liberalizm bir ideal olarak kalacaktu. Politik liberalizme gelince, parlamenterizm açısından cok az bir deneyimi olan bir toplumda ve yıkıcı tutihatçı/tilafçı çekişmelerinden sonra furkacıllk ruhundan son derece çekinen Kemalistleri, Cumhuriyet henủz iki yaşındayken demokrasiye geçemediler diye eleştirmek insaflı bir yaklaşım olmasa gerek. Unutmamak gerekir ki Bat'nın ekonomik, politik, bireysel ve entellekujel liberalizmi bağdaştırarak ozümseyebilmesi 2,5 ylizyılı aldı.

Ikinci konu ise, siyasi partinin yapısı ki, Prof. Zürcher bunun ụ̧̈ şekilde irdeleneceģini belirtiyor: parti programlari, ơrgütlenme şekli ve sosyal taban. TCF hakkında araşurmaya açık olan kaynaklann kısıth olması nedeniyle yukanda belirtilen üç kategori hemekadar derinlemesine incelenmemiş olsa da kitabın belkemigini oluşturan ogelerdir.

Kitap, Türk ulusal bağımsızlık hareketi sürecindeki iktidar mücadelesini anlatmakla başlıyor. Yazara göre, tarih yazımı bakımından Türk tarihi uzmanlan ya Osmanlılann son dönemlerini veya çağdaş dónemleri incelemektedir. Ancak 1918-1938 dönemi için sanki sóylenebilecek ve bilinecek herşey söylenmiştir ve biliniyordur. Klasik tarih yazımı bu konularda tüm gerçeği yansıttığına tarihçileri uzun süre inandırmıştır. Prof. Zürcher'in bu gözlemi sadece 1918-1938 yıllan için deģil, yerli ve yabancı bütüin Osmanlı-Türk tarihçileri için geçerlidir. 1950-1970 yıllan arasında çıkan anılar ve otobiyografiler olayların nedenleri ve gidişat hakkında bizlere klasik tarih uyarlamasından çok daha değişik ve zengin bilgiler sunuyorlar. Ömeğin, Falih Rifkı Atay, Ahmet Emin Yalman, Yakup Kadri Karaosmanoglu, Hüseyin Rauf Orbay, Ali Fuat Cebesoy'un anılannda Mustafa Kemal Ataturk, Ismet Inonü ve Kılıç Ali'nin yonumlanyla zaman zaman çelişen, bazen de çok daha açıklayıcı bilgiler vardır.

Tarihçiler Türk Istiklâl Savaşını incelerken direniş̧̧i kuvvetleri hep Kemalisuler ya da Ittihatçılar olarak sınıflandırular. Bu doğru bir sınıflandırmadır çünkủ Mustafa Kemal ve arkadaşlan da lttihatçı kőkenliydiler ve iktidar kavgası lttihaţ̧ı kliklerin arasında cereyan etmeye mahkûmdu. Direniş harekâunı başlatan da, sonra lider deģişikliklerine ragmen yürütenler de eski ltuihatçlard.

Doğu Anadolu ve Kilikya'nın Ermeni yurdu Ege ve Trakya'nın Yunan yurdu olduğu iddialan karşısında direnişe geçen Müdafa-i Milliye Cemiyeuleri Ittihat ve Terakki Furkasının taşra kollannca orgütlenmişti. Ituihatçılıktan Kuvay-1 Milliyeciliğe geçişte bir süreklilik vardır. Belki de bu nedenle Istiklâl Savaşı yıllannda bile (1919-1922) Mustafa Kemal Paşa'nın liderlił̧ine karşı muhalefet yapılmışur. Her iktidar mücadelesi gibi bu mücadelede de kişisel kıskançlık ve düşmanlıklarla, siyasi ve ideolojik eğilimlerin kanı̧ıımından doğuyordu.

Prof. Zürcher, Mustafa Kemal Paşa ile muhaliflerinin anlaşamadıklan noktalan şరyle sıralıyor. 1) Mustafa Kemal Paşa 1919'da Milli Kongrelerin toplanmasında ısrar ederken muhalifleri yerel kongreleri yeterli görüyorlard. 2) lutihatçılann ilk yeralu direniş örgütü olan Istanbul kökenli Karakol Cemiyeti bir türlü Anadolu ve Rumeli Müdafa-i Hukuk Cemiyetine katılmıyor, bağımsız davranmakta devam ediyordu. 3) Otorite boşluğunun sürdügü bu dónemde bir de Istanbul'daki Harbiye Nezaretinin başında olan Fevzi (Çakmak) ve Cevdet (Çobanlı) Paşalarla Mustafa Kemal Paşa'nın arasında anlaşmazlık çıkmışı. Fevzi ve Cevat Paşalar Mustafa Kemal'in Anadoluya tayinine onayak olmalanna rağmen Ankara'nın Istanbul'daki milliyetçilerden daha bağımsız bir yol gütmesinden rahatsız oluyorlardı. 4) Enver Paşa yurt dışından ve içinden oncelikle 
Sovyetlerin tam destek verebilecekleri Mustafa Kemal'e karşı bir altematif muhalefet orgütlemekle meşguldü. 5) Mustafa Kemal Paşanın muhalifleri arasında sadece solcu partiler ve Enver Paşalar deģil Mecliste bilhassa Erzurum'dan gelen tutucu milletvekilleri de vardı. Bu klik Sovyetlerle yakıınlaşmayı kınıyor tslamiyetin devlet dini olarak kalmasını ve Halifeye bağlıı̆̆ı vurguluyordu. 6) 1921'de Malta adasındaki lttihatçı sürgünler serbest bırakılıp Ankara'ya gelince muhalifler Mecliste lkinci grubu kurdular. Ikinci Grup Mustafa Kemal'i fazla radikal ve otokratik buluyordu.

Büyük Taarruzun yaklaş̧ığı donemde ve zafer sonucu yukarıdaki muhalefet unsurları Mustafa Kemal Paşa'ya karşı eyleme geçme firsatı bulamamışlardı. Cumhuriyetin ilânından tam bir hafta sonra Rauf Orbay kararın aceleye getirilip ne mecliste ne de kamuoyunda tartışılmadan geçirildiğini, dolayısıyla demokrasiyle bağdaşmadığnı savunuyordu. Bir yil sonra TCF'da toplanacak olan bütün muhalifler benzer eleşirilerle Orbay'ı izledi.

Bütün bunlara rağmen TCF'nı kurmaya karar verdiklerinde Mustafa Kemal'in silah arkadaşlan uzlaşmacı bir yol izlediler. Koşullannndan başlıcası Mustafa Kemal Paşanın meclis içindeki muhalefeti resmen tanıması ve partilerüstü bir hakem konumuna geçmesiydi. Bunun üzerine muhaliflerin bütün tartışma ve taktiklerinden haberli olan Mustafa Kemal bir konuşmasında hemen Halk Fırkasının başkanı ve Cumhurbaşkanı sıfatlarını birarada koruyacağını vurgular. Kanımca, Mustafa Kemal Paşa entellektüel liberalizmin olmadığı bir ortamda (ki buna kendi de dahildir) politik liberalizmi nasıl yerleştireceği konusunu çőzebilmiş dȩ̧ildi. Sonuçta, Yunanistan'dan gelen 400.000 mübadille ilgili yolsuzluklarla hükümeti suçlayan Orbay ve 10 arkadaşı gensoru açılması onergeleri reddedilince Halk Furkasından istifa ettiler.

Prof. Zürcher'in irdelemesine göre, Mustafa Kemal'in Meclis içi muhaliflerin sayısını sınırlı tutabilmek için uyguladıł̆ı taktikler TCF'nın başarısızlık nedenierinin başında geliyordu. Bunların başında Mustafa Kemal'in radikal cumhuriyetçi Ismet Paşa'yı bašvekillikten alıp, yerine ılımlı Fethi (Okyar) Bey'i getirerek muhalefeti sakinleştirmesi, Doğulu milletvekilleriyle (ömeğin Diyarbakır Milletvekili Zülfü (Tigrel) ile) uzlaşmaya giderek TCFa doğudan gelccek desteği başından durdurma çabalari geliyordu.

Durum boyleyken, TCF'n!n politikalan düşüncelerine uysun uymasın, ortak paydalan Mustafa Kemal ve onun kurduğu rejime muhalefet olan her egilimden kişilerin TCF'ye katıldığı bir gerçek. 1925'te "din ve şeriat" uğruna Şeyh Sait ve yandaşlarının isyanı üzerine parti programında dine saygılı olacağını vurgulayan TCF ile organik bir bağ kurulmamasına rağmen ideolojik bir bağlantı kuran Cumhuriyet rejimi TCF'yi feshetti. Bu baģlamda hernekadar kitabın dışındaki yorumlarına deģiniyorsak da Prof. Zürcher TCFnın ılımlı bir laiklik kavramını uygulayacağını ve bunun sayesinde 1990'ların Türkiyesinde köktendincilił̧in gündeme gelmeyeceğini savunuyor ("Aktüel", 21-27 Ocak 1993). Iran Islam Devrimi modelini, A.B.D.'nin komünizme karşı "yeşil kuşak" politikasını ve belki de dolayısıyla şeriatçılığa Suudi Arabistan'dan aktığı sőylenen parasal desteği göz önüne almadan, sırf ılımlı bir laiklik uygulansaydı, Türkiye'de köktendinciliğin bir sorun olmayacağı kanısında. Ama, sosyoloji bilimince saptanmış bir genelleme sosyal deģişimin zorlanmadan, dayatılmadan gerçekleşemeyeceģidir. Yıllardır ılımlı laikliģi uygulayan Mısır'ın sorunları ortada. Yukarıdan zorlama olmasa bugün ne A.B.D. ordusunda siyahlar ve beyazlar beraber talim yapıp savaşabilirlerdi, ne de dünyada kadın haklanı yaygınlaşabilirdi. 
TCF'nın kısa süren yaşamını Türkiye Cumhuriyeti'nin demokrasi yolundakı atılımı açısından ơlü doğmuş bir çocuk olarak nitelendirmek mümkün. TCF'nin kurulmasına karşı çıkmaması Mustafa Kemal'in toplumun nabzını yoklamak için kullandığı bir taktik olarak da degerlendirilebilir. Gene de, Mustafa Kemal kendisine mutlak diktatörlügü yakıştursaydı, ne 1924-25'de TCF ne de 1930'da Serbest Firka deneyimlerine girişirdi. Kısaca, herhalde Mustafa Kemal'den kurduğu cumhuriyeti daha 2. yılında belirsiz bir demokrasi kavramı uğruna riske atmasını beklemek gerçekçi bir tutum degiil.

Günümüzde tarihçiler ołarak tarihsel olayları çą̧daş ve kişisel değer yargılanmuzla yorumlayabiliyoruz. Zaten aksi olsa, mesleğimiz vakanüvislik olurdu. Ancak, gerçekçilikten aynlırsak yorumlarımız tarih yazımı ile gecmişin şarıan alunda yapılan eylemlerin ayrımında olmayan siyasal odaklarca dayanak olarak kullanılmaya açıkur. Omeğin, TCFnin kuruculan arasında halifeye/hilafete bağhı olanlar -hernekadar parti programına aksetmemişse bile- çoktu. Bugün de hilafet kaldınımasaydı Türkiye için daha olumlu olurdu görüşünü savunanlar var. Oysa, belirlendiği kadarnyla, hilafet hiçbir zaman Türklere geçmemişti. Osmanlı historiyografisinde ilk kez 18. y.y. sonunda Vasıf-ı Enderuni adh vakanüvisce Yavuz Sultan Selim'in 1517'de torenle son Memluk halifesinden hilafeti devraldığ mitolojisi -diplomatik maksatı nedenlerle- yaratıldı. Osmanh 1774'de ilk kez bir Müslüman topraģından vazgeçmek zorunda kalıyordu ve Küçük Kaynarca Antlaşmasının bir maddesị, Osmanlı Halifesinin Kınm Müslümanlan üzerindeki manevi etkisinin devam edeceğini kabul ediyordu. Ancak, hilafetin bir siyasi nüfuz alanı oldugưunun bilincindeki Osmanlı için bu madde ileride siyasi bir müdahale için açık kapı bırakırken, Islam felsefesini hiç tanımayan Ruslar için bu sadece ufak bir jestu. Çünkü, şayet bu mit gerçek olsaydı iki yüzyıl boyunca Osmanlı sultanlan herhalde bu derece ónemli bir sıfatı óncelikle kullanırlardı. II. Abdülhamid'in bu kavramı kullanması ise sadece Avrupa emperyalizmine karşı siyasi bir kozdu. Etkili olmasa da yeterince rahatsız edici bir koz. Avrupalılar hilafeti Caesaro-Papist bir yaklaşımla değgerlendiriyorlardi. Yạni, siyasi ve uhrevi otoritenin birelde tutulduğu bir makam. Oysa, hilafetle papalık arasındaki en büyük fark halifenin $\mathrm{Hz}$. Muhammed'in dünyevi işlevlerini devam ettiren bir makam olduğu, dini sorumluluğun ise şeyhülislam ve ulema tarafindan yürütüldügüü bir sistem olmasıdır. Dahası halifelik kurumu ne Osmanlıdır ne de Türktür. Bir Arap kurumudur. Aynca, teknik olarak Peygamber kabilesi Kureyş'ten birisinin bu yükümlülügüu devam ettirmesi gerekir. Günümüzde bunun en uygun adayı Ürdün Kralı Hüseyin. Ama teknik açıdan hilafeti en ozümseyebilecek olan aday bile buna kalkışmıyor. Öte yanda, makamın meşruiyeti kalmadığı bylesine açıkır ki meşru olabilecek tek aday Kral Hüseyin'in yerine Erzurum'un Isspir Kóyünden gelen Cemalettin Kaplan nezdinde halifelik kavramı resmen yozlaşmış ve bu kişi Köln'den Anadolu Islam Federasyonu kurdugunu ilân etmekle kalmayıp kendisine de halife payesini vermiştir. Türkiye Cumhuriyeti ise, yasal olarak üstlenilmeyen bir kurumu ortadan kaldırmışu, çünkü "halife" adı altında Osmanlı hanedanından gelebilecek olan siyasal rekabetin bilincindeydi. Bu nedenle, halifeliģin kaldınımasının dine saygı veya saygısızlıkla hiçbir bağlantısı yoktur. Dahası, halife sultan'a bağlılığın sadece bir duygusal ölçüt olarak bilimsel bir barometrede kullanılması, ulaşılan yargıların sağlık boyutlarını ciddi bir şekilde tehdit etmekle kalmayıp, okurlarını böyle bir metodu sorgulamaya davet ediyor. Eserin bu bağlamdaki katkısını da gözardı etmemek gerek. TCFı yanlılarının yanılgısı ve günümüzde tarışıımak istenen kurumun hiçbir zaman gerçek anlamda olmamıs olması tarihsel açıdan abesle iştigalden öteye gitmiyor. 
Metodoloji bakımından çağdaş degerlerle tarih yazımı ve tarihsel olayların o günler şartlarıyla değerlendirilmesi arasında bir uzlaşma/uyum sağlanması gerektiği kanısındayım. TCF denemesi zamanlı ve yerinde bir inceleme. Ancak, dilerim yazım ve gerçek tarihi şartlar arasında bir kơprü olarak kalsın ve hiçbirimizin resmi tarih dışı araşurmaları uzlaşmaz ikilemlere dayanak olmasın. (Burada "resmi tarih" dışı araştırmalardan kasıt sadece devlet ve hükümetlerin tarihi değgil, toplumun diğer katmanlannun da tarihidir.)

Sonuçta muhalefet olmanın sorumluluğu iktidar olmanın sorumluluğundan az deģildir derken, degerli dost ve meslektaşımı Prof. Zürcher'e Cumhuriyetimizin ilk dơnemindeki iktidar-muhalefet konusuna ışık tutan çalışması ile yakın tarihimize yapuğı katkıdan dolayı teşekkür etmeyi bir borç bilirim. 